\title{
Usability of UX Methods in Agrarian Sector - Verification
}

\author{
P. Šimek, J. Vaněk, J. Pavlík \\ Faculty of Economics and Management, Czech University of Life Sciences Prague, Czech Republic
}

\begin{abstract}
Anotace
Předložený článek pojednává o experimentálním ově̌ení tř́ metod UX testování webových aplikací pro oblast zemědělství, potravinářství, lesnictví, vodohospodářství, regionálního rozvoje a rozvoje venkova. Pro experimentální ověření, které bylo uskutečněno na Agrárním WWW portálu AGRIS, byly vybrány a kombinovány pětisekundový test, třicetisekundový test a podle předem připraveného scénáře test použitelnosti. Nejlepších výsledků dosáhl test použitelnosti a třicetisekundový test přinesl výsledky uspokojivé. Pětisekundový test byl prokázán jako pro danou oblast nepoužitelný.
\end{abstract}

\section{Klíčová slova}

UX, agrární portál, testování, WWW, uživatel, informační zdroj.

\begin{abstract}
The article deals with experimental verification of three distinct UX web application testing methods in areas of agriculture, food industry, forestry, water management and rural development. The verification was conducted using agrarian WWW portal AGRIS. The three analyzed methods were five-second test, thirty-second test and usability test with preset scenario. The usability test yielded best results. The results of thirty-second test were satisfactory while the five-second test proved to be unsuitable for the given area.
\end{abstract}

\section{Key words}

UX, agrarian portal, testing, WWW, user, information source.

\section{Introduction}

Recently, the issues of UI (User Interface) and UX (User eXperience) of web applications and software in general have reached the level of basic interaction with ICT (information and communication technologies) (Hassenzahl, 2006). More than before, the design is being tailored to fit end user needs (Moon Hee Jung, 2015). For instance, studies are being conducted that involve scenarios with common user problems (Jung, Min, 2015). Another example could be creation of graphical design and symbols for easy multimedia interaction between the user and the application (Ryo, 2014). Researchers and practitioners from many fields work with the UX conception every day. Despite the fact that UX design focuses on usability and aesthetics, the actual GUI (Graphic User Interface) and user experience are often vastly different (Byung ju, 2015). After many attempts to summarize and define the UX principles, there are still doubts that a unified consensus in this issue had been reached (Lallemand et al., 2015). UX is still quite young field of expertise and its full research scope and the operationalization of experience in general is yet to be determined (law et al., 2015).

UX design also comes with certain risks, such as providing undesired experience to users. UX methods are also missing normative tools to lead designers and developers (Puccilo and Canscini, 2014). Understanding user preferences is essential for both product designers (Chien et al., 2014) and web application developers. There are many techniques in testing UX design. The five-second test, for instance, which involves displaying visual or information output of the web for five seconds followed by a questionnaire, where user is asked about certain aspects (Doncaster, 2014). Other methods include eye tracking, which is commonly used during usability testing (Olmsted-Hawala et al., 2014), user satisfaction evaluation during their interaction with digital content (Zahidi et al., 2014), or usefulness study in terms of contextual and experience factors (MacDonald, Atwood, 
2014). In any case, the results are dependent on the target user group, as proven by many studies. For instance, there is huge gap between college students and seniors (Brajnik, Giachin, 2014).

All of the above apply in areas of agriculture, food industry, forestry, water management and rural development as well. UX and UI control element design is very important for effective use of web application by target user group, regardless whether its user group with specific needs or without (Benda, Šmejkalová, 2015).

\section{Materials and methods}

For the analysis of UX methods, three testing techniques were used: the five-second test, the thirty-second test and test of usability. The experimental evaluation was conducted using agrarian WWW portal AGRIS, which is one of the most used information sources for agrarian sector (agriculture, food industry, forestry, water management) and countryside area. This portal provides information since 1999 and the current version was built in 2011 according to the latest findings regarding common element layout of similar information sources and with technical equipment, user habits and their information literacy taken into account.

For the evaluation itself, 10 participants were carefully selected based on the following criteria:

- Users having average information literacy (using PC, web browser and internet portals)

- Users having a positive relation to agrarian sector or similar field (rural development, forestry, water management, food industry etc.)

- Users not being regular visitor of agrarian WWW portal AGRIS (in order not to distort results based on regular user habits and familiarity)

UX testing was conducted one individual at a time - always one respondent (user), one moderator, one evaluator and one technical worker being present. The entire process was divided into three parts in the following order (Figure 1):

1. Five-second test

2. Thirty-second test

3. Usability test of preset scenario

The five-second test was included in the evaluation to allow users to get user accustomed to the portal basics. Users we allowed to scroll through the page (but not click any links) and were asked for their first impression. The thirty-second test that followed had a goal to further improve user's basic orientation in the portal and prepare them for the usability test later. During the thirty-second test users were allowed to move around the portal at will. They were then asked to summarize their experience and fill in short questionnaire, where they marked each individual aspect of the portal on a 1 to 5 scale ( 1 being the best, 5 the worst). The questionnaire consisted of these five questions:

1. Is the portal graphics palpable?

2. Is the portal easy to navigate through?

3. Are the information widgets useful?

4. Is the information within the widgets relevant?

5. Is the space allocated for the main section big enough?

Besides the scoring system, users were also able to write a comment regarding each question.

The usability test followed a preset scenario (Figure 2). Users were asked to navigate through the portal while completing a list of task. The moderator always gave the testing subject details for each task and the technical worker then counted number of click required and time spent completing each task. The time needed to explain each step was not included. It was measured from the point when user actually started the task to the moment of its completion. Neither the moderator nor the technical worker were allowed to communicate with the test subjects beyond the basic task explanation to prevent passing of influence (Table 1).

The test was conducted using PC with Windows 7 operating system, Google Chrome web browser and $1355 \times 768$ pixel screen resolution. 


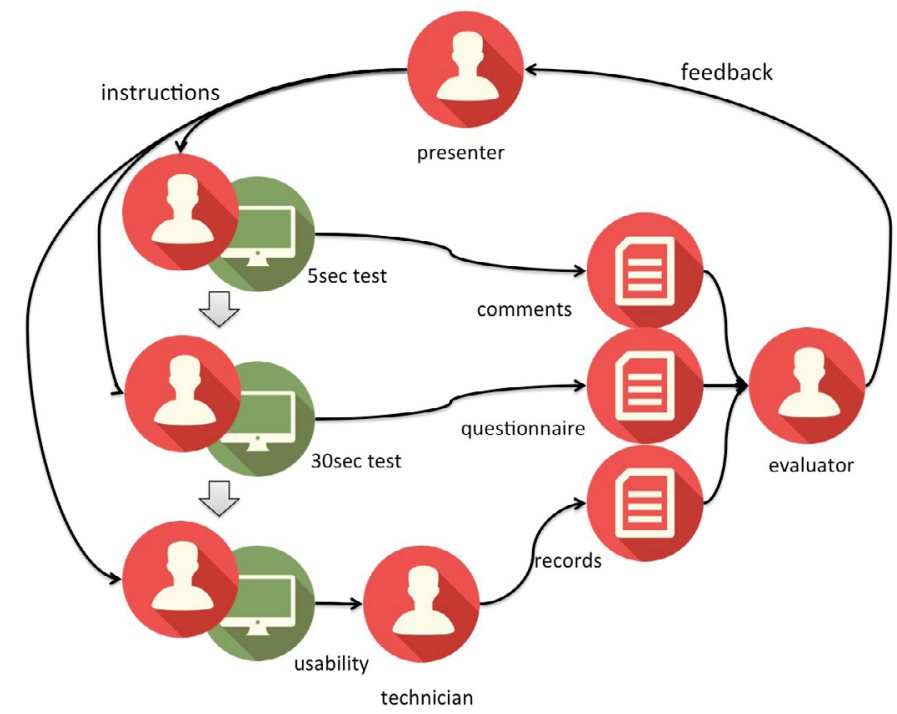

Source: Own research, icons from pelfusion.com

Figure 1: Usability test process.

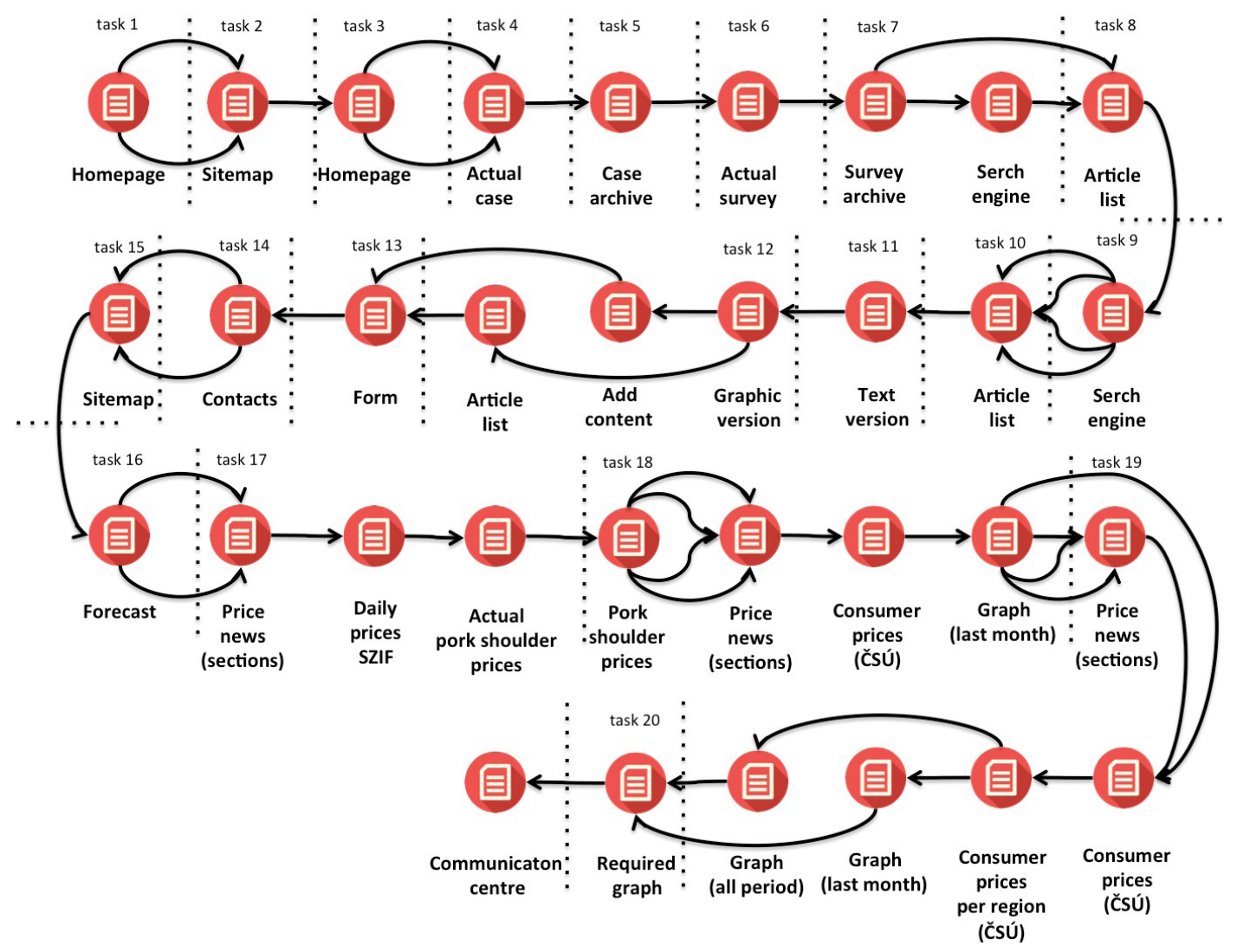

Source: Own research, icons from pelfusion.com

Figure 2: Scenario for usability test. 


\begin{tabular}{|c|c|c|c|c|}
\hline \multirow{2}{*}{ No. } & \multirow{2}{*}{ Task } & \multirow{2}{*}{ options } & \multicolumn{2}{|c|}{ optimal } \\
\hline & & & clicks & time \\
\hline 1 & Display server map & 2 & 1 & 1 \\
\hline 2 & Display front page & 1 & 1 & 1 \\
\hline 3 & Display articles regarding current issue & 2 & 1 & 4 \\
\hline 4 & Display issue archive & 1 & 1 & 4 \\
\hline 5 & Vote in current poll & 1 & 2 & 4 \\
\hline 6 & Display poll archive & 1 & 1 & 1 \\
\hline 7 & Display articles published on $15 / 04 / 2015$ & 2 & 2 & 5 \\
\hline 8 & Find link for the advanced search & 1 & 1 & 1 \\
\hline 9 & Display articles where the source is ASZ & 4 & 3 & 6 \\
\hline 10 & Display text version of the portal & 1 & 1 & 1 \\
\hline 11 & Display graphic version of the portal (without using the back button) & 1 & 1 & 3 \\
\hline 12 & Display form for adding a link & 2 & 2 & 5 \\
\hline 13 & Display contacts & 2 & 1 & 4 \\
\hline 14 & Display server map & 2 & 1 & 1 \\
\hline 15 & Display current weather forecast & 1 & 1 & 1 \\
\hline 16 & Display pricing news & 3 & 1 & 1 \\
\hline 17 & Find price of boneless pork shoulder for $15 / 04 / 2015$ (Daily meat prices in ČR - SZIF) & 1 & 4 & 12 \\
\hline 18 & $\begin{array}{l}\text { Display graphics for } 150 \mathrm{ml} \text { white yoghurt price progression during last month (Consumer } \\
\text { prices in ČR - ČSÚ) }\end{array}$ & 4 & 3 & 9 \\
\hline 19 & $\begin{array}{l}\text { Display graphics for } 150 \mathrm{ml} \text { white yoghurt price progression in Královéhradecký county } \\
\text { during April } 2015 \text { (Consumer prices in ČR - ČSÚ) }\end{array}$ & 8 & 12 & 22 \\
\hline 20 & Switch to AGRIS communication center & 1 & 1 & 3 \\
\hline & Total & - & 41 & 89 \\
\hline
\end{tabular}

Source: Own research

Table 1: Task overview, number of options on how to reach the goal., optimal number of clicks and optimal time.

\section{Results and discussion}

The five-second test did not yield any good results. Users were not able to define particular finding that would be usable for further improvement of the portal. Therefore this test was determined to be unsuitable for UX testing of agrarian information sources. Perhaps a questionnaire following the test could improve the results. Nevertheless, this test served as good introduction for users and as a basis for further testing.

The thirty-second test had much more useful results. The increase in allotted time allowed users to scroll the screen and navigate through links more thoroughly which lead to a deeper understanding on how the portal works. After the thirty second of free browsing users filled in a questionnaire, where they gave marks to each individual aspect of the portal on a 1 to 5 scale ( 1 was the best, 5 was worst).

The clarity of portal graphics was rated very positively, between 1 and 2. One user also commented on the graphics being too conservative.
But that is common practice and it is expected by most end users. Portal was rated as very easy to navigate, since all but one user gave it a 1 mark. The usefulness of widgets was rated between 1 and 3 , while the relevance of information within the widgets was rated between 1 and 4. One user found the right widget bar unnecessary. The space allocated for the main section was rated as sufficient. Marks for that question were in the range between 1 and 3 . One user pointed out that if the right bar was removed it would make the space for main section slightly larger.

The usability test (Table 2) turned out to be the most useful with results relevant for UX testing of agrarian web information sources. Users did not have any issues displaying the server map. Thanks to previous tests and own experience they were able to find the server map with one click spending an average of 5.8 seconds.

Displaying the front page took an average of 9.4 seconds and was also done with one click only by all tested users. Shortest achieved time was 6 seconds, while longest was 12 seconds. Users 


\begin{tabular}{|c|c|c|c|c|c|c|}
\hline \multirow{2}{*}{ No. } & \multirow{2}{*}{ Task } & \multicolumn{2}{|c|}{ clicks } & \multicolumn{3}{|c|}{ time } \\
\hline & & $\min$ & $\max$ & $\min$ & $\max$ & mean \\
\hline 1 & Display server map & 1 & 1 & 4 & 8 & 5.8 \\
\hline 2 & Display front page & 1 & 1 & 6 & 12 & 9.4 \\
\hline 3 & Display articles regarding current issue & 1 & 1 & 15 & 19 & 17 \\
\hline 4 & Display issue archive & 1 & 1 & 3 & 11 & 7.2 \\
\hline 5 & Vote in current poll & 2 & 2 & 8 & 13 & 10.2 \\
\hline 6 & Display poll archive & 1 & 1 & 2 & 6 & 3.4 \\
\hline 7 & Display articles published on $15 / 04 / 2015$ & 2 & 4 & 7 & 25 & 14.4 \\
\hline 8 & Find link for the advanced search & 1 & 1 & 2 & 15 & 7 \\
\hline 9 & Display articles where the source is ASZ & 2 & 5 & 8 & 30 & 17.2 \\
\hline 10 & Display text version of the portal & 1 & 1 & 5 & 9 & 6.4 \\
\hline 11 & Display graphic version of the portal (without using the back button) & 1 & 2 & 16 & 30 & 24.2 \\
\hline 12 & Display form for adding a link & 2 & 2 & 8 & 35 & 20.2 \\
\hline 13 & Display contacts & 1 & 3 & 15 & 41 & 26.4 \\
\hline 14 & Display server map & 1 & 1 & 3 & 5 & 3.6 \\
\hline 15 & Display current weather forecast & 1 & 1 & 3 & 4 & 3.2 \\
\hline 16 & Display pricing news & 1 & 1 & 2 & 7 & 4.2 \\
\hline 17 & $\begin{array}{l}\text { Find price of boneless pork shoulder for } 15 / 04 / 2015 \text { (Daily meat prices } \\
\text { in ČR - SZIF) }\end{array}$ & 4 & 6 & 18 & 30 & 23.8 \\
\hline 18 & $\begin{array}{l}\text { Display graphics for } 150 \mathrm{ml} \text { white yoghurt price progression during last } \\
\text { month (Consumer prices in ČR - ČSÚ) }\end{array}$ & 3 & 6 & 20 & 44 & 30.2 \\
\hline 19 & $\begin{array}{l}\text { Display graphics for } 150 \mathrm{ml} \text { white yoghurt price progression } \\
\text { in Královéhradecký county during April } 2015 \text { (Consumer prices in ČR } \\
\text { - ČSÚ) }\end{array}$ & 12 & 21 & 49 & 68 & 59 \\
\hline 20 & Switch to AGRIS communication center & 1 & 1 & 4 & 25 & 14.4 \\
\hline & Total & & & & & 307.2 \\
\hline
\end{tabular}

Source: Own research

Table 1: Task overview, number of options on how to reach the goal., optimal number of clicks and optimal time.

mostly searched for type Homepage link, but after not finding it, they tried clicking the portal logo, where the link actually is. This is a good example of users using common practice and standard conventions and the result is highly determined by user information literacy and own experience.

Link for articles regarding the current issue is located in the Issues widget or under the main news section on front page. Reaching this page took between 15 and 17 seconds and subset of the users did use the second option. Most of the time needed to complete this task was used scrolling through the widgets and searching for the correct link, since most users correctly assumed that the link would be somewhere in the widget.

Fourth task involving displaying of issues archive was completed rather quickly, since users already knew where to search for the proper link. The time needed was between 3 and 11 seconds and the average was 7.2 seconds.

Next task which was voting in a poll took an average of 10.2 seconds. Users found the link in the widget but some time was also spent reading the poll contents before actual voting. The following task of displaying poll archive was completed very quickly thanks to previous experience and was completed in an average of 3.4 seconds.

Searching for articled with given publishing date did not cause any problems. Only one user used the search bar, while the rest used the quick search option directly inside the calendar, which is available on one of the widgets. Time to complete this task was between 7 and 25 seconds.

Time required to find link for advanced search ranged between 2 and 15 seconds, with the average being 7 seconds. The user with the worst time wrote a comment that the advanced search link is located on the right spot (near the basic search) but is not very well distinguished.

Searching for all articles with ASZ source using the advanced search was not problematic for most of the users. They took between 8 and 
30 second to complete this task while most of this time was spent getting accustomed to all the fields of the search form. Two users typed the "ASZ" into the search bar and one used "with all the words" option and the other used "exact match" option. The rest of tested users used the field "source" where they picked ASZ.

Displaying the portal's text version (not the mobile version) took between 5 and 9 seconds and everyone did it in just one click. Based on previous experience they knew to look for it in the technical navigation next to language selection. However, getting back to the graphic version caused a lot of issues. The time was ranging between 18 and 30 and one user failed to complete the task entirely. Everyone assumed the link would be located at the same position (technical navigation) while it was actually at the end of the website.

Form to add a link was found in average of 20.2 seconds (range between 8 and 35 seconds). Most users easily found the first link to add content but then spent some time reading the instructions on how to select a content type (links, articles, notifications).

Displaying contacts took between 15 and 41 seconds. Almost all users searched for the link near the technical navigation or in footer. Only after not finding it at those location they started to search the widgets. This link is located in one of the last widgets "About server" on the right hand part of the screen. Two users actually followed the link "Communication center" from the footer.

Task number 14 was displaying the server map, which is the same as task number 1. It was included in the testing scenario in order to compare the time on a simple task users have already completed. It took an average of 3.6 seconds to complete, while the first time (task no. 1) it was 5.8 seconds.

To display current weather forecast users instinctively used the option to click forecast images on the top right hand corner widget. Average time was 3.2 seconds.

Pricing news was found in 4.2 seconds on average and always with one click. Most users clicked the "Price" headline or the chart of price development of one of the commodities in a widget. Three users clicked the "Prices" link in the portal's header. The following tasks involving the pricing news were more difficult. Displaying prices of particular commodity (pork shoulder) for a particular date $(15 / 04 / 2015)$ took an average of 23.8 seconds (between 22 and 30 seconds). Displaying prices for another commodity (white yoghurt) in the past month took 30.2 seconds on average (range from 20 to 44 seconds) and was achieved between 3 and 6 clicks. Users spent a lot of time reading through elements of the displayed pricing table. A more specified task involving displaying of the pricing development of the same commodity, but only for a particular county and a specified timespan (April 2015) took almost an entire minute on average and users needed between 12 and 21 clicks to complete it.

The last task was to navigate to the communication center of the AGRIS portal., which took 14.4 seconds on average. The two users who accidentally got to the communication center while searching for contacts managed to complete this task within 4 seconds thank to their previous experience.

\section{Conclusion}

Experimental evaluation proved that the five-second test as a standalone UX technique is not suited for testing in area of agrarian information sources. But in conjunction with other methods it can serve as an introduction to get users accustomed to the web application. The thirty-second test followed by questionnaire yielded more useful results, mostly thanks to list of preset topics which users could use to bounce off of.

The most effective UX testing method from the three evaluated was usability test. It depends heavily on each individual user background, information literacy and previous experience with similar web applications. Without proper testing subject selection, it can provide vastly distorted results.

Methods of UX testing were evaluated using agrarian WWW portal AGRIS. The main goal was to determine whether or not these techniques are suitable for testing in agrarian sector and associated fields. However, the obtained results can be also used to improve the actual usability of the portal itself.

\section{Acknowledgement}

The knowledge and data presented in the paper were obtained as a result of the Grant No. 20151032 of the Internal Grant Agency titled "UI/UX issues in relation to application for rural development and associated fields". 
Corresponding author:

Ing. Pavel Simek, Ph.D.

Department of Information Technologies, Faculty of Economics and Management,

Czech University of Life Sciences Prague, Kamýcká 129, 165 21, Prague, Czech Republic

E-mail: simek@pef.czu.cz

\section{References}

[1] Benda, P., Šmejkalová, M. Web Interface for Education of Mentally Disabled Persons for Work in Horticulture. Agris on-line Papers in Economics and Informatics. 2015, Vol. 7, No. 1, p. 13 - 19. ISSN 1804-1930.

[2] Brajnik, G., Giachin, C. Using sketches and storyboards to assess impact of age difference in user experience. Published in International Journal of Human Computer Studies. 2014, Vol. 72, No. 6, p. 552 - 566. ISSN 1071-5819.

[3] Byung ju, K. Analysis of the GUI Design for the Responsive Web Based on the UX Design Factors -Focused on Male and Female Undergraduates. Journal of the Korean Society of Design Culture. 2015, Vol. 21, No. 2, p. 19 - 30. ISSN 1598-6497.

[4] Chien, C.-F., Lin, K.-Y., Yu, A. P-I. User-experience of tablet operating system: An experimental investigation of Windows 8, iOS 6, and Android 4.2. Computer \& Industrial Engineering. 2014, Vol. 73, p. $75-84$. ISSN 0360-8352.

[5] Doncaster, P. The UX Five-Second Rules: Guidelines for User Experience Design's Simplest Testing Technique. Elsevier Inc., 2014, p. 108. ISBN 978-012800534-7.

[6] Hassenzahl, M., Tractinsky, N. User experience - A research agenda. Behaviour and Information Technology. March 2006, Vol. 25, No. 2, , p. 91 - 97. ISSN 0144-929X.

[7] Junk, E. C., Min, K. UX Scenario Development based on Chatting UI for IoT Home Appliances Enhancing UX for LG HomeChat. Proceedings of the International Seminar on Computation, Communication and Control. 2015, Vol. 4, p. 37 - 40. ISSN 2352-538X.

[8] Lallemand, C., Gronier, G., Koenig, V. User experience: A concept without consensus? Exploring practitioners' perspectives through an international survey. Published in Computers in Human Behavior. February 2015, Vol. 43, p. 35 - 48. ISSN 0747-5632.

[9] Law, E. L.-C., Van Schaik, P., Roto, V. Attitudes towards user experience (UX) measurement. International Journal of Human Computer Studies. June 2014, Vol. 72, No. 6, p. 526 - 541. ISSN: $1071-5819$.

[10] MacDonald, C. M., Atwood, M. E. What does it mean for a system to be useful? An exploratory study of usefulness. Proceedings of the Conference on Designing Interactive Systems: Processes, Practices, Methods, and Techniques, DIS. Association for Computing Machinery, 2014, p. 885 - 894. ISBN 978-145032902-6.

[11] Moon Hee Jung, A. Study on User eXperience(UX) Design in Internet of Things. The Journal of The Korea Institute of Electronic Communication Sciences, 2015, Vol. 10, No. 7, p. $819-824$. ISSN 1975-8170.

[12] Olmsted-Hawala, E., Holland, T., Quach, V. Usability Testing. Book chapter of Eye Tracking in User Experience Design. Elsevier Inc., 2014. p. 49 - 80. ISBN 978-012408138-3.

[13] Puccilo, F., Canscini, G. A framework for user experience, needs and affordances. Design Studies. March 2014, Vol. 35, No. 2, p. 160 - 179. ISSN 0142-694X.

[14] Ryo, S. H. UX Contents Through Visual Symbol of the Wonhaeng Eulmyo Jeongri Euigwe. Published in Journal of Korean Society of Communication Design. 2014, Vol. 17, No. 2, p. 93 - 108. ISSN 2092-9633. 
[15] Zahidi, Z., Lim, Y. P., Woods, P. C. Understanding the user experience (UX) factors that influence user satisfaction in digital culture heritage online collections for non-expert users. Proceedings of 2014 Science and Information Conference, SAI 2014, p. 57 - 63. ISBN 978-098931931-7. 